\title{
A longitudinal model to increase the enrollment and graduation of Alaska Native/American Indian engineering undergraduates
}

\section{Dr. Herbert P. Schroeder, University of Alaska Anchorage}

Herb Ilisaurri Schroeder received his $\mathrm{PhD}$ in civil engineering from the University of Colorado Boulder. $\mathrm{He}$ is currently Vice Provost for ANSEP (Alaska Native Science \& Engineering Program) and Founder at the University of Alaska Anchorage and Professor of Engineering. In 2009, Dr. Schroeder was honored by the creation of an endowed chair in his name at the University of Alaska Anchorage with $\$ 4.4$ million in donations from the ANSEP partner organizations. He is the recipient of the White House 2004 Presidential Award for Excellence in Science, Mathematics, and Engineering Mentoring; the Alaska Federation of Natives 2005 Denali Award, the greatest honor presented by the Federation to a non-Native; and the NACME 2009 Reginald H. Jones Distinguished Service Award.

\section{Dr. Linda P. Lazzell, University of Alaska Anchorage}

Linda Lazzell is Vice Chancellor Emerita for Student Affairs at the University of Alaska Anchorage. During her tenure at the university, Dr. Lazzell led the development of student-centered programs and services that increased student success, including the establishment of the Alaska Native Science \& Engineering Program as the first residential academic learning community on the campus. Dr. Lazzell is a recipient of the 2009-2010 Thomas M. Mangoon Excellence in Counseling Award from ACPA (American College Personnel Association), Commission for Counseling and Psychological Services; the 2009 Grand Gold Award, Student Recruitment Video, District VIII from CASE (Council for Advancement and Support of Education), for "Villagers in the City"; and the 1992 ACPA Outstanding International Program of the Year. Dr. Lazzell received her EdD in counseling psychology from Argosy University Sarasota. She is a higher education consultant, a licensed professional counselor, and board certified counselor supervisor. 


\title{
A longitudinal model to increase the enrollment and graduation of Alaska Native/American Indian engineering undergraduates
}

\begin{abstract}
Native American enrollment and graduation rates remain among the lowest of all ethnic and racial student cohorts at universities in the United States. This paper describes the impact of the Alaska Native Science \& Engineering Program (ANSEP) on the preparation, enrollment, persistence, and academic success of Alaska Native engineering students.

ANSEP has evolved into a longitudinal education model that provides a continuous string of components beginning with students in sixth grade, continuing on through high school, into engineering and science undergraduate majors, and through graduate school to the PhD. ANSEP provides inspiration, guidance, and opportunity for students from 95 Alaskan communities. The model represents 18 years of effort and has been developed with the awareness that a fragmented approach that focuses on one academic level is not adequate to deal with the scope of the problem and ultimately falls short. Each component is based on the fundamental Native principle of working together in a community.
\end{abstract}

ANSEP infuses values of community, family, and collaboration in all elements of the program. ANSEP promotes readiness, including early identification of students, motivation, and preparation, bridging programs, learning communities, internships, and research opportunities that provide intense preparation for university and industry involvement.

ANSEP students are successful at rates far exceeding national and state averages. Middle School Academy students complete algebra 1 by the end of eighth grade at a rate of $83 \%$. The national average is $26 \%$. More than half of ANSEP high school students graduate engineering ready, compared to $4 \%$ of minority students nationwide who do so. Summer Bridge students take advanced mathematics courses for credit, have paid internships, and are awarded scholarships upon successful completion of the component, with $96 \%$ successfully transitioning to BS STEM majors. More than $70 \%$ of all ANSEP students who begin BS STEM degrees graduate.

ANSEP students recognize the importance of community and teamwork. Research findings suggest that they perceive the ANSEP-related experiences as important contributors to their success as students. The findings further suggest that ANSEP students experience high levels of academic and social engagement, peer support, congruence with the university, and commitment to complete their degrees.

\section{Introduction}

The Alaska Native Science \& Engineering Program (ANSEP) focuses on providing inspiration, guidance, and opportunity for Alaska Native and American Indian students to pursue engineering and other STEM degrees at the University of Alaska campuses. ANSEP is a longitudinal model that works with students from the time they are in middle school all the way through to the professions and the $\mathrm{PhD}$. The program raises the bar for academic preparation for college, increases university recruitment, first-to-second-year retention, and graduation rates through 
hands-on middle and high school outreach initiatives, rigorous summer bridging programs, and focused undergraduate and graduate academic communities. Programmatic components are grouped in the four broad categories of Pre-College, Summer Bridge, University Success, and Graduate Success.

\section{Background}

ANSEP was founded in 1995 as an Alaska Native engineering recruitment and retention program within the school of engineering at the University of Alaska Anchorage (UAA) with a single Alaska Native engineering undergraduate. It was quickly discovered that the Alaska Native students who were applying to and arriving at the university were very underprepared for college-level mathematics and science. Prior to the fall 1996 semester, only 13 Alaska Native students had enrolled in UAA's introduction to engineering course and 3 Alaska Native students had graduated with a bachelor's of science degree in engineering in the fifteen-year history of its undergraduate engineering degree program.

In our conversations with the teachers and administrators in the K-12 system it was revealed that most believed that Alaska Native students were not interested in pursing careers in engineering or science. Many teachers stated that their Alaska Native students did not have the interest, motivation or capacity to complete chemistry, physics, and trigonometry by the time they graduated from high school. These courses were often not offered in most of the non-urban high schools that had high populations of Alaska Native students. Most of the Alaska Native students we were meeting stated that they could not have a career in engineering or science.

The situation at UAA was similar. Many of the Alaska Native students who arrived at UAA had taken very few high school science courses and their mathematics level was at algebra 1 or lower. It would be years before these underprepared undergraduates would be eligible to take their first introduction to engineering course. The lack of academic preparation for these incoming first-year engineering students presented a formidable problem.

We searched for a solution where we could connect directly with the K-12 students. It had to result in the K-12 students being motivated to complete chemistry, physics, and trigonometry in high school. It had to develop the self-efficacy required to continue to pursue a challenging STEM curriculum. At the university, we had to find a way for Alaska Native and American Indian students to survive and then excel. We needed to develop an approach that was cost effective and led to successful university STEM course completion.

ANSEP began in 1995 with one private industry donation for student scholarships. There was no university, state or federal funding. Weekly pizza meetings, study sessions, co-enrollment, mentoring, and networking quickly grew from one student to ten students with Student Affairs collaboration. A dedicated living/learning community in the residence halls was added in 1996. The Summer Bridge component for incoming first-year students and paid summer internships for continuing ANSEP undergraduates were added in 1998. Additional funding was raised from private industry, Native corporations, and philanthropic organizations to provide programmatic and scholarship support for the growing student population. 
ANSEP expanded its student community to include Alaska Native and American Indian undergraduates pursuing other STEM degrees. The Pre-College component, undergraduate research opportunities, and the Graduate Success component were added later. STEM undergraduates from other underrepresented ethnic and racial minority groups began seeking out the program because of the welcoming and supportive community. Additional non-state funding was raised to provide scholarships for the new students.

In 2001, ANSEP was awarded its first National Science Foundation (NSF) Louis Stokes Alliances for Minority Participation (LSAMP) and Partnerships for Innovation (PFI) grants. There were 22 Native undergraduates engaged in the program. During the 2009-2010 academic year ANSEP had 700+ participants from sixth grade through PhD. As of May 2012, there have been 267 Native STEM BS graduates from the University of Alaska Anchorage and the University of Alaska Fairbanks (UAF) since 1995. In 2001, ANSEP organized an alliance of universities and community colleges to disseminate the model across the nation. This alliance has expanded into eight additional states.

To support this work \$35 million in cash has been raised from private industry, Native corporations, philanthropic organizations, state and federal agencies, and individuals since 1995. ANSEP partners provided $\$ 6.5$ million for a 14,000 square foot building to house ANSEP on the Anchorage campus of the University of Alaska Anchorage. They also provided \$4.4 million for an endowed chair for ANSEP so that Alaska Native and American Indian STEM students will have a faculty advocate in perpetuity. The 2012-2013 year budget is approximately $\$ 4$ million, with $\$ 0.8$ million from the State of Alaska general fund base. University funding was gradually obtained from the State of Alaska general fund base to institutionalize the core program staff originally funded through phase 1 and 2 of the NSF LSAMP grants. State funds now provide partial support for the ANSEP Pre-College component through the State of Alaska Department of Education and Early Development. The Graduate Success component is funded through the Alfred P. Sloan Foundation.

\section{ANSEP Longitudinal Model}

The ANSEP longitudinal model engages a group of more than 100 private corporations, philanthropic organizations, state and federal agencies, universities, high schools, and middle schools. The objective is to effect a systemic change in the hiring patterns of Indigenous Americans in the fields of science, technology, engineering and mathematics (STEM) by increasing the number of individuals on a career path to leadership in STEM fields.

It is widely accepted that the United States has fallen behind in producing the science and engineering talent necessary to maintain its technological edge. As noted by the National Action Council for Minorities in Engineering, ${ }^{34,35}$ the National Academies, ${ }^{33}$ the National Science Foundation, ${ }^{37}$ the Committee on Science, Engineering, and Public Policy, ${ }^{21}$ and others, the United States is confronted with a problem that may require a generation to fix. The magnitude of the effort we face requires systemic solutions and sustained funding streams. We believe there is adequate funding within the current system. The problem is that much of the money spent nationwide is not producing the results we need. If the approaches we have taken in the past were 
effective the problem would not persist. In many cases we are paying for failure and have been for 40 years.

There are countless efforts underway around our nation that focus on students once they arrive at our universities. These efforts attempt to remediate academic deficiencies and bring students up to a level where they can be successful in college. This solution starts in the middle and attempts to undo what in some cases is 12 years of inadequate K-12 education.

ANSEP is a longitudinal string of components that provides inspiration, guidance, and opportunity for students. Beginning with sixth graders, structured programs lead students each step of the way through middle school and high school, into the undergraduate years, on to graduate school, and into professional life. At each level the goal is to create empowerment and excitement around engineering and science. ANSEP has arrived at this model after nearly 18 years of effort, aware that a fragmented approach that focuses on one area or level is not adequate to deal with the scope of the problem and ultimately falls short.

Each component is based on the fundamental Native principle that community is more important than the individual. ANSEP's goals are to:

- build a welcoming environment at the University;

- infuse values of community, family, and collaboration in all elements of the program;

- promote readiness, including early identification of students, motivation, and preparation;

- create bridging programs as well as internship and research opportunities that provide intense preparation for university and industry involvement.

The Urban Institute conducted an evaluation of the National Science Foundation Louis Stokes Alliances for Minority Participation (LSAMP). The Urban Institute found that many of the strategies employed by LSAMP alliance organizations fostered the academic and social integration of underrepresented minority students pursuing bachelor's degrees in STEM fields. ${ }^{19}$ The ANSEP undergraduate retention strategies that are consistent with the LSAMP strategies include: summer bridge programs, scholarships, peer study groups, skills building seminars, academic advising, tutoring, mentoring, undergraduate research opportunities, attending and presenting at scientific conferences, internships, and career awareness activities.

In addition, ANSEP provides a middle school academic enrichment component, a high school academic component, an undergraduate on-campus academic living/learning community, course co-enrollment, social and recreational activities, American Indian Science and Engineering Society (AISES) student club advising, the ANSEP Building learning facility, and a graduate student component. See Chart 1 for an overview of the components of the ANSEP longitudinal model. 


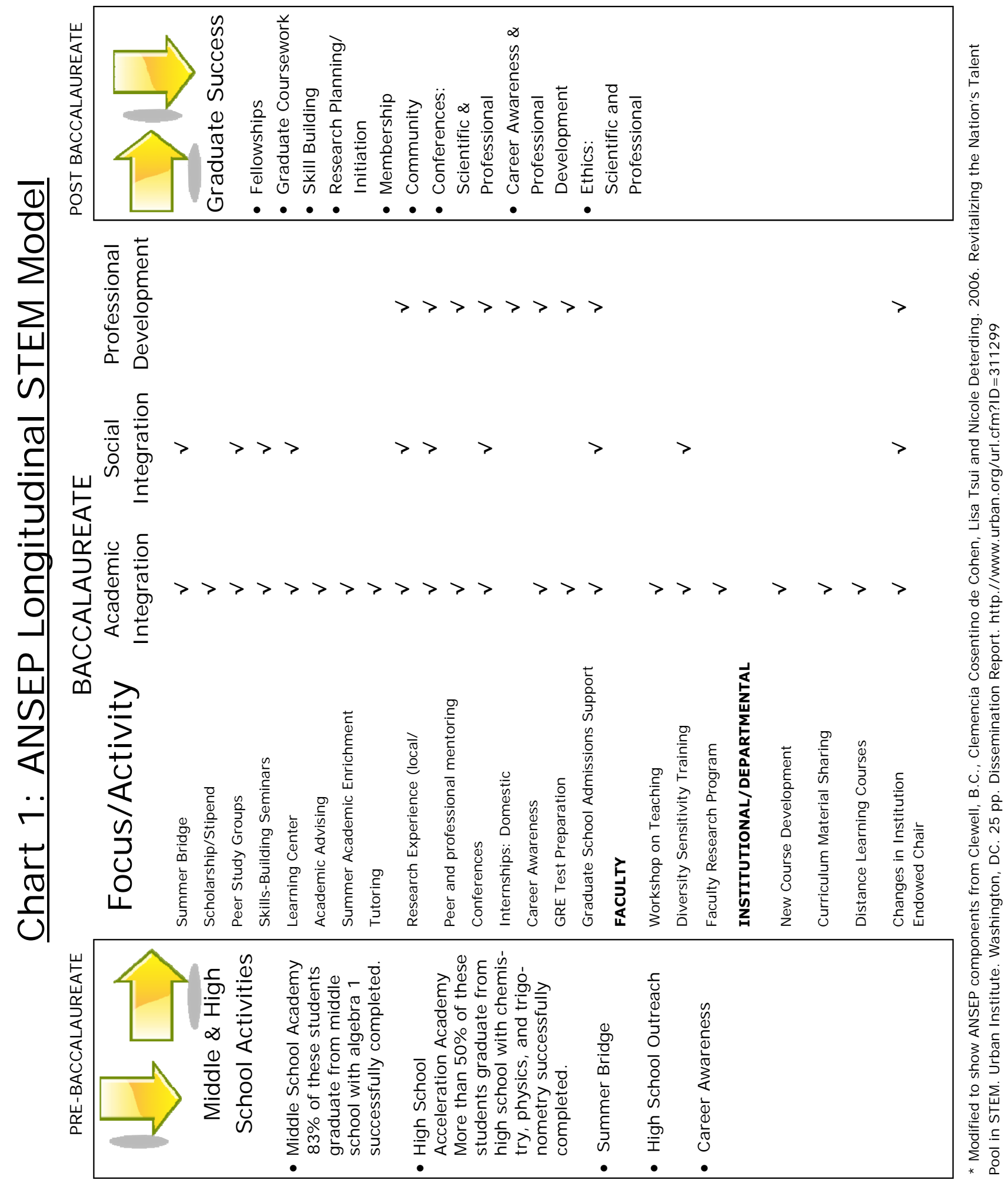

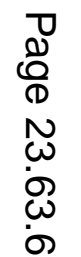




\section{Pre-College Components}

Middle School Academy

In partnership with the ExxonMobil and the Bernard Harris Foundation, ANSEP started the Middle School Academy during summer 2010. The Academy, the first component of the ANSEP longitudinal model, is a twelve-day, academic, and residential component that focuses on increasing the mathematics and science skills of middle school students while introducing them to college life. The main goal is to inspire students to successfully complete algebra 1 or higher prior to graduation from eighth grade. Eighty-three percent of our participants attain this objective, compared to the national average of 26 percent for all students completing eighth grade nationwide. ${ }^{39}$ Graph 1 presents ANSEP middle school mathematics achievement data.

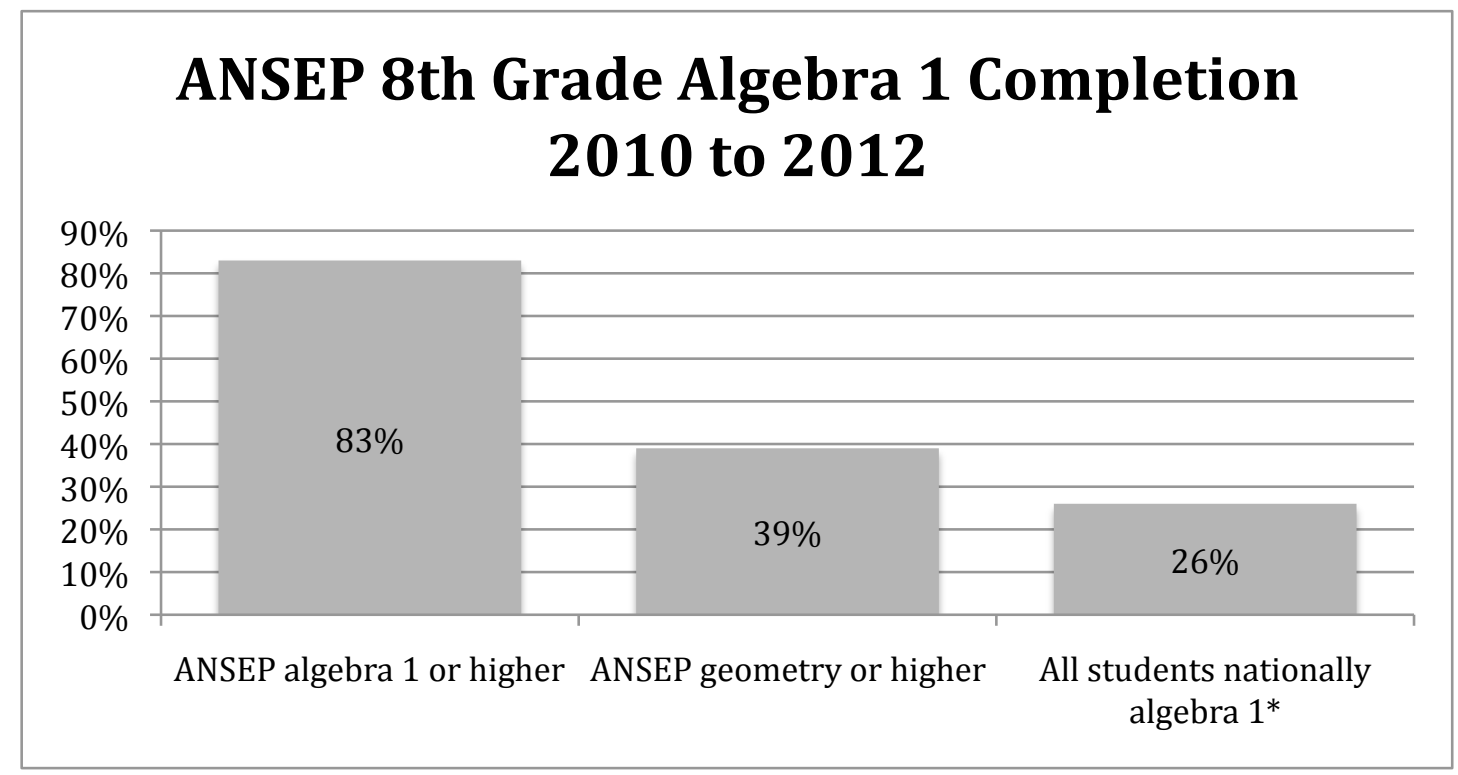

Graph 1

Students completing Algebra 1 or higher by the end of eighth grade, ANSEP student data compared to national student data.

*Nord, C., Roey, S., Perkins, R., Lyons, M., Lemanski, N., Brown, J., and Schuknecht, J. (2011). The Nation's Report Card: America's High School Graduates (NCES 2011-462). U.S. Department of Education, National Center for Education Statistics. Washington, DC: U.S. Government Printing Office.

On the first day of the Middle School Academy, each student assembles a top-end computer and loads the operating system and Microsoft Office software. Students then use the computers on various tasks related to the daily classes they take for the remainder of the Academy. Students attend classes that include problem solving, research, and communication skills incorporated with biology, chemistry, physics, environmental sciences, earth sciences, engineering and design concepts, and field excursions all led by industry professionals, certified classroom teachers, and university faculty.

Activities are organized to provide STEM career visioning through hands-on experiments, projects, and field experiences for students. Activities include designing, building, and testing a 
balsa wood bridge, rainbow trout dissection, genetics experiments, and watershed modeling. These activities, and many others, are designed to provide students with an understanding of how science and mathematics are applied in STEM careers.

Each summer ANSEP hosts multiple sessions with 54 middle school students per session who are currently in sixth, seventh, and eighth grade and have at least a "B" average in science and mathematics courses. The number of selected students is equally divided by grade and by gender within each grade. All of the students live on the UAA Anchorage campus in the residence halls, learn to navigate the campus, and dine like college students.

Acceleration Academy

The objective for Acceleration Academy, the second component of the ANSEP longitudinal model, is for each student to arrive for their freshman year at the university fully prepared socially and academically at an accelerated level for BS degrees in science and engineering. Acceleration Academy high school students:

- live in the residence community on the Anchorage campus for five weeks each summer;

- take two university-level courses in engineering, science or mathematics;

- earn college credits towards a STEM degree;

- gain knowledge and understanding about college life;

- learn to work as a team;

- complete hands-on career exploration activities in engineering, biology, geology, genetics, fisheries, and other science fields every weekend;

- build the confidence needed to be successful at any academic level, and

- earn scholarship money for use at any University of Alaska institution.

All of the Acceleration Academy courses are taught by university faculty. There are at least 50 Acceleration Academy students each summer. Students are eligible beginning the summer after graduation from eighth grade. Past students have completed most of the mathematics necessary for a degree in engineering prior to graduation from high school. Ninety-two percent of all past Academy students have advanced at least one level in mathematics or science during each Academy session and $75 \%$ have completed two full college classes and advance two full levels.

\section{Computer Assembly}

In Computer Assembly, high school students who have not been connected through the ANSEP Middle School Academy assemble a top-end computer and earn the right to keep it by completing trigonometry, physics and chemistry, and by showing future computer assembly students how to build computers. Students learn to use AutoCAD, Working Model, MS Office, GIS, and other software relating to STEM careers. Since 2002, ANSEP Pre-College students have assembled over 1,000 computers, and more than half of those who have now graduated from high school have successfully completed all three classes. This compares to what NACME (2008) calls the " $4 \%$ percent problem" of underrepresented ethnic and racial minority students nationwide who graduate from high school "engineering eligible." 34 This component has been replicated with similar outcomes in eight states with our alliance partner universities and colleges. 


\section{Summer Bridge Component}

ANSEP Summer Bridge, the third component of the ANSEP longitudinal model, is for calculusready or further advanced students who have just graduated from high school. This component includes a for-credit, university-level mathematics class and a paid engineering or science internship with a partner organization. There are internship sites in town and in the field.

In town Summer Bridge includes eight-week internships, daily calculus/other advanced mathematics for-credit classes, evening calculus/mathematics study sessions with undergraduate peer mentors from the University Success component, Friday "brown bag" sessions with practicing professionals from the community, and weekend group activities. Field Summer Bridge includes one week of safety training, a for-credit calculus or other advanced mathematics class, and a five-week field internship working with scientists and engineers. Each Summer Bridge student makes a presentation for the partner sponsors at the end of the summer. Students who successfully complete the component requirements are awarded scholarships.

Summer Bridge students:

- $\quad$ work on real projects with practicing engineers and scientists;

- earn money for college;

- complete a college-level mathematics class for credit toward their BS degree;

- solidify their vision of a career as a scientist or engineer;

- learn to navigate on the campus; and

- develop peer and university faculty relationships.

There have been 250 Summer Bridge students so far. Of these, 96\% have successfully transitioned to BS degree programs in engineering and science. Twelve organizations currently sponsor Summer Bridge students.

\section{University Success Component}

University Success is the fourth component of the ANSEP longitudinal model. During this component ANSEP works to foster an engaged learning community focused on academic success and professional development. Since 1995, there have been 267 Native scientists and engineers who have graduated from the University of Alaska Anchorage and the University of Alaska Fairbanks. There were 500 Native STEM students enrolled at these University of Alaska institutions during the fall 2012 semester.

The ANSEP undergraduate program-life retention rates are above 70\%. ANSEP is designed to be an academic community that focuses on those areas where students have traditionally had difficulties. ANSEP students understand the importance of community. ANSEP helps students find ways to work together to be successful. Each student is required to complete and adhere to a contract that lists the requirements of the program in order to be in good standing and eligible for scholarships and internships.

The ANSEP academic community for the University Success component is comprised of students, university faculty and staff, and external partners focused on the academic success as 
well as the personal and professional development of each student. Students are teamed. They are co-enrolled in classes, participate in organized study groups, are provided with opportunities for peer and professional mentoring, do undergraduate research projects, work summer internships, and participate in planned group social and professional development activities.

The goal is for each University Success student to:

- be effective at working together and understand the importance of a supportive community/study group;

- $\quad$ earn money needed for college through internships;

- $\quad$ earn scholarship support;

- develop a network of peer mentors;

- develop a network of professional mentors;

- complete a research project as an undergraduate;

- develop leadership skills by making presentations to students and professionals by describing summer internships and research projects;

- develop leadership skills by leading recitation sessions and mentoring other students;

- graduate with a BS in a STEM discipline; and

- transition to graduate school or the STEM professions.

Students are teamed in the academic community, supported by peers and professionals, working together for success. Many students live and study together on campus. Others come to ANSEP organized study groups. Building a supportive peer group is a big part of why ANSEP students are successful. ${ }^{13,30}$ What follows is a detailed description of ANSEP retention strategies.

- Scholarships. ANSEP industrial partners provide many of the merit-based scholarships. Scholarships play an important role in retention, as many of our students would not be able to overcome the financial hurdle presented by educational costs without them. ANSEP alumni have an alumni dinner each December where they raise scholarship funds for the undergraduates. Approximately \$0.6 million in scholarships were awarded during the 2012-2013 academic year.

- Peer Study Groups. Recitation sessions are designed to strengthen skills in the gateway courses like calculus, chemistry, computer programming, and physics. Junior, senior, and graduate students who have previously completed the course with a grade of " $\mathrm{B}$ " or higher lead the sessions. Students meet weekly and are required to get up and solve problems on the board and be able to explain what they are doing for the other students in the session. We have found this to be a very effective learning tool.

- Skill Building Seminars. Students are required to attend weekly meetings. These provide an opportunity for students to learn skills necessary for academic and professional success. ANSEP faculty and staff, other students, faculty, and professionals from our partner organizations come each week to talk about success. Professionals from the community come to meet the students, make presentations, and explain jobs and opportunities available in engineering and science fields. ANSEP students make presentations on their research projects and internships so that others can see the array of career options. These meetings are an opportunity for us to see the students each week and to identify and mitigate problems before they jeopardize a student's academic success. We work to keep these sessions very informal and relaxed. We share pizza, bar- 
b-q, and traditional Native foods. The sessions are a powerful networking opportunity for the students with professionals, faculty, staff, and the other students.

- Learning Center. In October 2006, ANSEP moved into a new building on the Anchorage campus of the University of Alaska Anchorage. The ANSEP Building is a home for all of the minority STEM students on the Anchorage campus. ANSEP students have access to the building in the evenings and on weekends.

- Academic Advising. Advising sessions with faculty advisers and ANSEP staff are required at least twice each semester for first- and second-year students. We also have peer advisors available in the ANSEP building.

- Summer Academic Enrichment. All students are required to work in their field of study in paid summer internships or research projects within ANSEP partner organizations. These applied learning opportunities provide personal growth, professional development, and the cash students need to attend the university.

- Tutoring. ANSEP peer tutors are available all day, every day in the ANSEP building.

- Research Experiences. Undergraduate research opportunities are provided for the students through our graduate schools, industrial partner organizations, federal agencies, and state agencies. ANSEP works to connect each student with undergraduate research opportunities and foster mentoring relationships with current $\mathrm{PhD}$ candidates and research faculty. Students are encouraged to conduct research with research scientists in one of their summer internships. ANSEP works locally with the University of Alaska campuses, National Science Foundation, and National Institute of Health grantees to incorporate undergraduate research funding in their work. Nationally, ANSEP encourages students to consult the directory of active REU sites and apply directly to those sites. ANSEP alumni graduate students working on the various research projects make presentations at weekly undergraduate team building meetings.

- Peer mentoring. Peer mentoring is incorporated in every component of the model, including peer study/recitation groups, co-enrollment in classes, skill-building seminars at the weekly meetings, research and internship experiences where students work together, tutoring, peer advising, social and academic enrichment activities, and others.

- Professional Mentoring. ANSEP students are mentored by professionals during their research experiences, summer internships, at the weekly meetings, and by ANSEP faculty and staff.

- Conferences. Students travel with faculty to national and international conferences and sometimes present their research findings. Annually, ANSEP sends students to the American Indian Science and Engineering Society (AISES) national conference.

- Internships. Summer internships are required so students earn the money they need for school, clarify their vision of a career in science or engineering, expand their professional network, and provide additional mentoring opportunities. Internships are productive for the employer and educational for the student. Internship sites in town are structured with time each week for interns to make field trips to suppliers and attend "brown bag" sessions where professionals explain important issues related to their profession.

- Career Awareness. Students are provided with opportunities to increase their career awareness through internships, research projects, weekly meetings, professional mentoring, peer mentoring, advising sessions, and conferences.

- GRE Test Preparation. ANSEP connects students and provides funding for private tutoring, small group instruction, local courses, and online courses. 
- Graduate School Admissions Support. ANSEP provides financial, mentoring, and test preparation support for ANSEP students who are interested in graduate school. ANSEP provides some funding for students to visit schools they are considering attending.

- Workshop on Teaching. Dr. Raymond Landis and Dr. Vincent Tinto have led workshops on the UAA campus. ANSEP has sent 10 faculty and staff to Dr. Landis' Chautauqua short course titled "Enhancing Student Success Through a Model 'Introduction to Engineering' Course."

- Enrichment Activities. ANSEP incorporates academic, curricular, and co-curricular enrichment activities in order to improve instructional performance and increase the motivation, performance, and progression of talented students within STEM undergraduate degree programs in preparation for graduate degree programs.

- Distance Learning Courses. All students are provided with the opportunity to take courses offered on other University of Alaska campuses through distance learning. Many of our students on the rural campuses take classes this way.

\section{Graduate Success Component}

ANSEP Graduate Success, the fifth component of the ANSEP longitudinal model, extends the ANSEP community and support into graduate school. With the assistance of the Alfred P. Sloan Foundation, the University of Alaska Anchorage, and the University of Alaska Fairbanks, ANSEP started the Graduate Success component in the fall 2008 semester. Alaska Native and American Indian graduate students can earn fellowships and tuition support for STEM master's and $\mathrm{PhD}$ degrees. Each master's student receives $\$ 32,000$ in fellowship funds and tuition costs. Each $\mathrm{PhD}$ student receives $\$ 38,000$ in fellowship funds and tuition costs.

The ANSEP model is based on the fundamental indigenous value that stresses the importance of community before the individual. ANSEP undergraduate and graduate students work together to assure mutual success in each component. Graduate students have the opportunity to make a significant contribution to our undergraduate community because they have already demonstrated success by completing a STEM undergraduate degree. Graduate students are role models and mentors for all of the other students in our program. During the 2012-2013 academic year, there are 16 Alaska Native and American Indian STEM graduate students being funded. Each student is required to complete and adhere to a contract that lists the requirements of the program in order to be in good standing. Since beginning in the 2008-2009 academic year, 9 Native graduate students have earned STEM degrees from University of Alaska institutions, with $2 \mathrm{PhDs}$ and 7 master's degrees.

The goal for each ANSEP Graduate Success student is to:

- develop a network of peer mentors and colleagues;

- develop a network of faculty mentors;

- make professional presentations at national and international conferences;

- be skilled at developing research proposals;

- be skilled at conducting independent research;

- be skilled at developing technical papers;

- mentor undergraduate students;

- organize study groups for graduate and undergraduate ANSEP participants; and

- earn a master's or PhD in a STEM discipline. 


\section{Grow Your Own PhD}

In 2008, ANSEP started the Grow Your Own PhD component. This component supports students pursuing $\mathrm{PhDs}$ in engineering and science who choose to travel to other universities for their degree. The goal is to have our students become faculty and return to our university. Support includes a fellowship and travel. Candidates are guaranteed a faculty position upon successful degree completion. There are two students currently participating. One will graduate this spring from the University of Colorado Boulder where he is earning a PhD in Civil Engineering. The second is at Purdue University where she is working on a PhD in Engineering Education.

\section{ANSEP Building}

The ANSEP Building provides 14,000 square feet of space that is forever reserved for the students as a hub for learning, safety, and a community of belonging. The Tlingit dugout canoe design of the structure has become a landmark in our state. Students meet in the ANSEP Building to study and form the relationships that bring them success. The impact will endure for generations.

The ANSEP partners provided the funding necessary for construction. The students drove the design process and were adamant that the building overtly reflect Native culture and values. The building opened in October 2006. Having dedicated space provides an excellent venue for each of the ANSEP programmatic components.

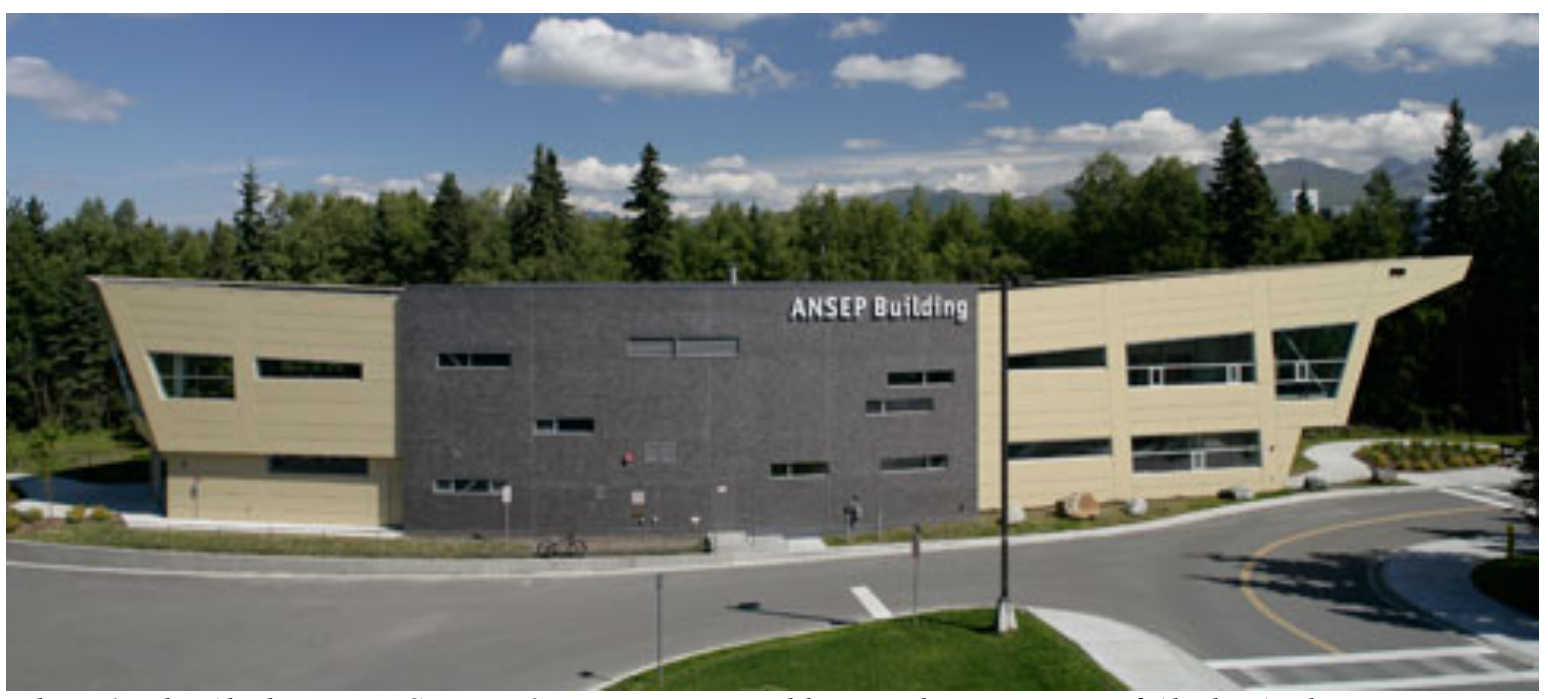

Photo 1: The Alaska Native Science \& Engineering Building on the University of Alaska Anchorage campus.

Students, industrial partners, and university faculty and staff gather daily to learn from each other. All of the campus programmatic activities are conducted in the ANSEP Building. It has become a home. 


\section{Foundations and Evaluation}

\section{ANSEP Pre-College Program Foundation}

Students who come to college more academically prepared are more likely to be successful and persist in college. 1, 4, 8,42 Adelman asserted that, "Academic intensity of the student's high school curriculum counts more than anything else in precollege history in providing momentum in completing a bachelor's degree" (p. xviii). ${ }^{1}$ In 1984, Falk and Aitken reported that a barrier for Native American college students was a lack of sufficient academic preparation while they were in high school. ${ }^{24}$ More than twenty years later, Freeman and Fox stated, "American Indian/Alaska Native high school students who graduated in 2000 were less likely to have completed the core academic track than their peers of other racial/ethnic groups" (p. 64). ${ }^{25}$ NACME noted that the high school dropout rate in 2009 for Native American ninth through twelfth grade students in the U.S. was $6.3 \%$, twice the dropout rate of the white student cohort. ${ }^{35}$ In its 2012 recommendations for federal and state K-12 policy considerations, NACME stated that "support needs to be provided to see AI/AN students through to high school graduation, stemming the drop-out rate, and increasing overall academic achievement levels" (p. 2). ${ }^{35}$

Research findings suggest that early encouragement from K-12 teachers and high school mentors to pursue engineering and other STEM degrees may have a positive effect on student interest and motivation and serve as an early intervention for students who might not otherwise consider pursuing STEM degrees. ${ }^{23,38}$ These early interventions may motivate students to take more challenging mathematics and science courses in middle school and high school. ${ }^{38}$ Taking more challenging courses prior to postsecondary enrollment may increase student confidence in their mathematics and science skills and lead higher persistence in a STEM degree program. ${ }^{23}$

A focus on pre-college preparation is necessary to increase the number of underrepresented ethnic and racial minority university students in the STEM fields. ${ }^{18}$ Chubin, May, and Babco stated, "An effective pre-college program must (1) promote awareness of the engineering profession, (2) provide academic enrichment, (3) have trained and competent instructors, and (4) be supported by the educational system of the student participants (i.e., the school and/or school district)" (p. 79). ${ }^{18}$ Chubin et al. further recommended focusing the efforts on academic enrichment rather than remediation. Pre-college preparation strategies that were recommended included scholarships, summer academic skills development programs, weekend enrichment classes, and pre-engineering classes in high schools. ${ }^{18}$

ANSEP pre-college components incorporate and build on these and other theories and strategies for effective pre-college academic preparation to increase the enrollment and degree completion of Alaska Native and American Indian students in STEM degree programs leading to careers in STEM fields.

\section{ANSEP Pre-College Program Evaluation}

Pre-college academic preparation and achievement were consistent themes in the findings of 2007 and 2010 evaluations at the University of Alaska Anchorage (UAA) related to the Alaska Native engineering undergraduates participating in ANSEP. These students were invited to be 
involved in the evaluations by completing an assessment tool related to their experiences and opinions on what contributed to their academic success and persistence at UAA. The respondents were asked to offer advice to high school students from their communities who might be interested in studying engineering at college. The most common advice offered by the Alaska Native engineering respondents was for the high school students to take more mathematics and science courses in high school, followed by the advice to study hard and be serious about their academic achievement in high school. Some respondents commented that they were behind in their college studies because they did not take enough mathematics and science courses in high school or they were not serious enough about studying in high school. These engineering respondents also offered advice on various ways the high school students from their communities could gain knowledge and experiences related to engineering before going to college, including participating in pre-college academic enrichment programs and summer bridge programs. ${ }^{13,30}$

\section{University Success Foundation}

ANSEP university recruitment and retention strategies for Alaska Native and American Indian engineering and other STEM undergraduates have been developed using theories and best practices related to student involvement, $, 5,6,8$ student retention, ${ }^{42,43,10,12}$ a local model of student expertise, ${ }^{40}$ the power of self-efficacy beliefs, ${ }^{911,44}$ and diverse university learner groups. $3,11,14,15,16,22,26,27,29,31,41,42,45$

ANSEP components and strategies are consistent with research on best practices for STEM undergraduate success. ${ }^{2,19,25,28,32,36,37}$ Professional guidance on diversifying the STEM workforce and pathways to the professorate ${ }^{17,20,21,18,33}$ has also informed ANSEP faculty and staff in the best approaches to providing an effective undergraduate STEM retention program, real-world internship experiences, undergraduate research opportunities, pathways to STEM graduate studies, career mentoring and networking, and on-site job interviews for graduating seniors with employers in STEM-related fields. The ANSEP longitudinal model for the preparation, recruitment, retention, and graduation of Alaska Native and American Indian STEM undergraduates has been influenced by the successful strategies employed by other university retention programs for underrepresented ethnic and racial minority STEM undergraduates presented in the literature, during the National Science Foundation LSAMP and PFI federal grantee annual conferences, and during dissemination conferences and meetings with ANSEP alliance universities and community colleges.

\section{University Success Evaluation}

The positive impact of the existing practices of ANSEP recruitment and retention strategies for targeted STEM undergraduates has been supported in evaluations within the past six years. ${ }^{13,30}$ ANSEP conducts evaluations of programs every three years. The next evaluation will be in 2013 .

The 2007 evaluation included a twenty-year longitudinal study of the academic records of Alaska Native engineering undergraduates enrolled at the University of Alaska Anchorage. There was a statistically significant $(p<.05)$ increase in the number of Alaska Native enrollees compared to the number of non-Alaska Native enrollees in the introduction to engineering courses in the ten years after the ANSEP university retention program began compared to the 
prior ten years. There was a statistically significant $(p<.05)$ increase in the number of bachelor of science degrees in civil engineering awarded to Alaska Native enrollees compared to nonAlaska Native enrollees in the ten years after ANSEP started compared to the prior ten years.

An assessment tool was designed as a part of the 2007 evaluation to study currently enrolled Alaska Native undergraduate ANSEP participants' perceptions of the value and importance of the ANSEP University Success components and their perceptions of their interactions with ANSEP peers, faculty and university staff, and the university system. The data collected were analyzed for evidence of social and academic integration, educational goal commitment, congruence with the university, and self-efficacy. ${ }^{30}$ The assessment tool was administered again during a 2010 evaluation with consistent findings. ${ }^{13}$ Selected findings are presented here.

The 2007 and 2010 results suggested that Alaska Native ANSEP engineering respondents perceived ANSEP-related retention strategies and experiences has having important and positive impacts on their success as students. Results were consistent over time (see Table 1).

Table 1

University-related experiences perceived as important contributors to UAA Alaska Native ANSEP engineering student success, 2007 \& 2010 student cohort comparison. ${ }^{13}$

Item response choices selected by $60 \%$ or more of the respondents 2007 2010

Attending ANSEP Friday pizza meetings $95.3 \% \quad 100.0 \%$

Attending ANSEP tutoring/recitation sessions $95.3 \% \quad 91.7 \%$

Taking classes with other ANSEP students $90.7 \% \quad 91.7 \%$

Developing friendships with ANSEP students $88.4 \% \quad 91.7 \%$

Socializing with ANSEP students outside of class $86.0 \% \quad 94.4 \%$

Studying with ANSEP students outside of class $83.7 \% \quad 88.9 \%$

Receiving funding from ANSEP $83.7 \% \quad 86.1 \%$

Having contact with ANSEP faculty/staff $74.4 \% \quad 75.0 \%$

Participating in an ANSEP summer internship $74.4 \% \quad 66.7 \%$

Participating in ANSEP social/recreational activities $65.1 \% \quad 75.0 \%$

$\mathrm{n}=43$ respondents in 2007; 36 respondents in 2010. An item response choice selected by $60 \%$ or more of the survey respondents was considered an important finding. There were 22 University and ANSEP item choices. Statistical significance of 2007 and 2010 differences presented here were determined by the two-tailed Fisher's exact test. No statistically significant differences exist, at the .05 level of significance.

The 2007 and 2010 ANSEP assessments also included questions to measure the Alaska Native ANSEP engineering respondents' levels of academic and social integration, student-institution fit, self-efficacy, and commitment to their educational goals of obtaining bachelor's degrees in engineering or other STEM fields. Results were consistent over time (see Table 2). 
The questions related to student academic and social integration were:

- "I feel like the ANSEP faculty/staff care about my success as a student."

- "I feel comfortable being a student at UAA."

- "I feel like other ANSEP students care about my success as a student."

- "ANSEP helps motivate me to continue studying engineering." (2007)

- "ANSEP helps motivate me to continue studying engineering, science (including mathematics) or technology (including construction management)." (2010)

- "ANSEP provides resources to help me be more academically successful."

- "I enjoy what I am studying."

The 2007 and 2010 results suggested that Alaska Native ANSEP engineering respondents experienced high levels academic and social integration at UAA. See Table 2 for results.

The question related to student congruence with UAA, or student-institution fit, was:

- "I feel comfortable being a student at UAA."

The 2007 and 2010 results suggested that Alaska Native ANSEP engineering respondents experienced high levels of congruence with UAA, or student-institution fit. See Table 2 for results.

The questions related to self-efficacy and commitment to educational goals were:

- "I feel confident that I will earn a bachelor's degree."

- "I feel confident that I will earn a bachelor's degree in engineering." (2007)

- "I feel confident that I will earn a bachelor's degree in engineering/STEM." (2010)

- "I feel confident that what I am studying will lead to the job/career I want."

- "I enjoy what I am studying."

The 2007 and 2010 results suggested that Alaska Native ANSEP engineering respondents experienced high levels self-efficacy and commitment to obtaining their educational goals. See Table 2 for results.

2007 and 2010 evaluation results suggested that ANSEP university retention strategies were deemed important contributors to academic success and positively influenced the academic and social integration of Alaska Native ANSEP engineering respondents and their sense of belonging. Results suggested that these respondents experienced high levels of peer support from each other and high levels of help from ANSEP faculty and staff. Alaska Native engineering respondents reported experiencing high levels of congruence, or student-institution fit, within the UAA campus environment and high levels of self-efficacy and commitment to completing bachelor's degrees in engineering or other STEM fields. ${ }^{13,30}$ 


\section{Table 2}

UAA Alaska Native ANSEP engineering students ' perceptions of academic and social integration, congruence with UAA, self-efficacy and educational goal commitment, 2007 \& 2010 student cohort comparison. ${ }^{13}$

"Quite Often" and "Almost Always" Combined Responses

$2007 \quad 2010$

I feel like the ANSEP faculty/staff care about my success as a student $\quad 97.7 \% \quad 100.0 \%$

I feel confident that I will earn a bachelor's degree $\quad 97.7 \% \quad 91.7 \%$

I feel confident that I will earn a bachelor's degree in engineering** $\quad 97.7 \%$

I feel confident that I will earn a bachelor's degree in engineering/STEM** ------- $\quad 94.4 \%$

I feel comfortable being a student at UAA $\quad 93.0 \% \quad 91.7 \%$

ANSEP helps motivate me to continue studying engineering*** $\quad 93.0 \%$

ANSEP helps motivate me to continue studying engineering/STEM*** ------ $\quad 97.2 \%$

I feel confident that what I am studying will lead to the job/career I want $\quad 93.0 \% \quad 88.9 \%$

ANSEP provides resources to help me be more academically successful $\quad 93.0 \% \quad 97.2 \%$

I enjoy what I am studying $\quad 83.7 \% \quad 74.3 \%$

I feel like other ANSEP students care about my success as a student $\quad 81.4 \% \quad 75.0 \%$

$n=43$ respondents in 2007; 36 respondents in 2010 except to "I enjoy what I am studying" where $\mathrm{n}=35$. The combined item choices of "quite often" or "almost always" selected by $60 \%$ or more of the survey respondents are considered important findings in the studies. **The 2007 survey question "I feel confident that I will earn a bachelor's degree in engineering" was changed in 2010 to "I feel confident that I will earn a bachelor's degree in engineering/STEM” to be an inclusive question for all ANSEP STEM students surveyed in 2010. ***The 2007 survey question "ANSEP helps motivate me to continue studying engineering" was changed in 2010 to "ANSEP helps motivate me to continue studying engineering/STEM" to be an inclusive question for all ANSEP STEM students surveyed in 2010. Only the 2007 and 2010 Alaska Native ANSEP engineering student responses are presented in Table 2. Statistical significance of 2007 and 2010 differences presented here were determined by the two-tailed Fisher's exact test. No statistically significant differences exist, at the .05 level of significance.

\section{Conclusions}

ANSEP was founded as an Alaska Native undergraduate engineering recruitment and retention program within the school of engineering at the University of Alaska Anchorage to address low enrollment and graduation rates for that student cohort. The program incorporated national best practices for student retention and STEM success. Early academic success and engagement components included co-enrollment in courses, group study sessions, scholarships, and weekly team building and networking meetings. To increase student success, ANSEP added an academic learning community within the residence halls, a summer bridge component, and undergraduate summer internships. ANSEP later expanded its student community to include Alaska Native and American Indian undergraduates pursuing other STEM degrees and at other University of Alaska institutions. 
To fortify STEM academic preparation for college and successful transition to careers in STEM fields, ANSEP expanded its undergraduate success program offerings to include undergraduate research opportunities and interventions at the pre-college and graduate school levels, transforming into a longitudinal model. More recently, STEM undergraduates from other underrepresented ethnic and racial minority groups who sought out the program because of its supportive community were welcomed by ANSEP.

Alaska Natives and American Indians are underrepresented in the STEM career fields and one of the obstacles can be linked to challenges within the educational system. ${ }^{35}$ One of these challenges is graduating from high school. Alaska Native and American Indian high school student drop out rates are among the highest of all ethnic and racial student cohorts. ${ }^{35}$ The ANSEP longitudinal model provides inspiration, guidance, and opportunity for Native American and other students interested in STEM fields throughout their educational journey.

ANSEP students at all levels have been successful at rates far exceeding national and state averages. More incoming Alaska Native and American Indian undergraduates are enrolling at University of Alaska institutions academically prepared to pursue STEM degrees. These students are earning undergraduate and graduate STEM degrees at higher rates. An increasing number of funding agencies and organizations have been willing to become involved and invest in ANSEP inspired by the demonstrated successes of ANSEP students and the remaining need to motivate more Alaska Native and American Indian students to prepare for and pursue STEM careers.

While the results reported here are for a specific target population at a public university in Alaska, the ANSEP longitudinal model has been replicated at other universities and colleges in other states. A coordinated and longitudinal educational approach beginning in middle school through graduate school is recommended to increase the Alaska Native and American Indian student participation, retention, and graduation rates in undergraduate and graduate engineering degree programs at other higher education institutions.

\section{References}

1 Adelman, C. (2006). The toolbox revisited: Paths to degree completion from high school to college. Washington, DC: U.S. Department of Education.

2 American Society for Engineering Education (ASEE). (2012). Going the distance: Best practices and strategies for retaining engineering, engineering technology and computing students. Washington DC: American Society for Engineering Education.

3 Antonio, A. L. (2003). The influence of friendship groups on intellectual self-confidence and educational aspiration in college. The Journal of Higher Education, 75(4), 446- 471.

4 Astin, A. W. (1977). Four critical years. San Francisco: Jossey-Bass.

5 Astin, A. W. (1982). Minorities in American higher education. San Francisco: Jossey- Bass.

6 Astin, A. W. (1984). Student involvement: A developmental theory for higher education. Journal of College Student Personnel, 25(4), 297-308.

7 Astin, A. W. (1985). Achieving educational excellence. San Francisco: Jossey-Bass. 
8 Astin, A.W. (1993). What matters in college: Four critical years revisited. San Francisco: Jossey-Bass.

9 Bandura, A. (1997). Self-efficacy: The exercise of control. New York: Freeman.

10 Bean, J. P., \& Eaton, S. B. (2000). A psychological model of college student retention. In J. M. Braxton (Ed.), Reworking the student departure puzzle (pp.48-61). Nashville, TN: Vanderbilt University Press.

11 Bean, J. P., \& Eaton, S. B. (2001-2002). The psychology underlying successful retention practices. Journal of College Student Retention, 3(1), 73-89.

12 Bean, P. E., \& Noel, L. (1980). What works in student retention. Iowa City, IA: The American College Testing Program and the National Center for Higher Education Management Systems.

13 Behrens, T. T. (2010). The merit of the Alaska Native Science \& Engineering Program student success components to the University of Alaska Anchorage, Alaska Native STEM undergraduate participants. External Evaluation Report, 180 pages.

14 Belgarde, M. J., \& LoRE', R. K. (2003-2004). The retention/intervention study of Native American undergraduates at the University of New Mexico. Journal of College Student Retention: Research, Theory \& Practice, 5(2), 175-203.

15 Benjamin, D. P., Chambers, S., \& Reiterman, G. (1993). A focus on American Indian college persistence. Journal of American Indian Education, 32(2), 24-39.

16 Braxton, J.M., Hirschy, A. S., \& McClendon, S. A. (2004). Understanding and reducing college student departure. ASHE-ERIC Higher Education Report, 30(3). San Francisco: Jossey-Bass.

17 Building Engineering Science Talent (BEST). (2004). A bridge for all: Higher education design principles to broaden participation in science, technology, engineering, and mathematics. San Diego, CA: Building Engineering Science Talent.

18 Chubin, D. E., May, G. S., \& Babco, E. L. (2005). Diversifying the engineering workforce. Journal of Engineering Education, 94(1), 73-86.

19 Clewell, B. C., Cosentino de Cohen, C., Tsui, L., \& Deterding, N. (2006). Revitalizing the nation's talent pool in STEM: Science, technology, engineering, and mathematics. Washington DC: The Urban Institute.

20 Committee on Equal Opportunities in Science and Engineering (CEOSE). (2004). Broadening participation in America's science and engineering workforce. The 1994- 2003 Decennial \& 2004 Biennial Reports to Congress. Arlington, VA: National Science Foundation.

21 Committee on Science, Engineering, and Public Policy (COSEPUP), 2007. Rising Above the Gathering Storm: Energizing and Employing America for a Brighter Economic Future. Washington, D.C.: The National Academies Press.

22 Demmert, Jr., W. G. (2001). Improving academic performance among Native American students: A review of the research literature. Charleston, WV: ERIC Clearinghouse on Rural Education and Small Schools (ERIC Document Reproduction Service No. 463917).

23 Eris, O., Chachra, D., Chen, H., Sheppard, S., Ludlow, L., Rosa, C., Bailey, T., \& Toye, G. (2010). Outcomes of a longitudinal administration of the persistence in engineering survey. Journal of Engineering Education, 99(4), 371-395.

${ }^{24}$ Falk, D. R., \& Aitken, L. P. (1984). Promoting retention among American Indian college students. Journal of American Indian Education, 23(2), 24-31.

25 Freeman, C., \& Fox, M. (2005). Status and Trends in the Education of American Indians and Alaska Natives (NCES 2005-108). U.S. Department of Education, National Center for Education Statistics. Washington, DC: U.S. Government Printing Office.

26 Jackson, A. P., Smith, S. A., \& Hill, C. L. (2003). Academic persistence among Native American college students. Journal of College Student Development, 44(4), 548-565. 
27 Kuh, G. D., \& Love, P. G. (2000). A cultural perspective on student departure. In J. Braxton (Ed.), Rethinking the student departure puzzle: New theory and research on college student retention (pp. 196-212). Nashville, TN: Vanderbilt University Press.

${ }^{28}$ Landis, R. B. (2005). Retention by design: Achieving excellence in minority engineering education. National Action Council for Minorities in Engineering (NACME) Monograph. Retrieved September 8, 2007, from http://www.nacme.org/

29 Larimore, J. A., \& McClellan, G. S. (2005). Native American student retention in U.S. postsecondary education. New Directions for Student Services, 2005(109), 17-32.

30 Lazzell, L. (2007). An assessment of the impact of university retention program strategies on the retention and academic success of Alaska Native undergraduate engineering students. Ed.D. dissertation, Argosy University/Sarasota, United States -- Florida. Dissertations \& Theses. Publication No. AAT 3354477.

31 Mayo, J., Murguia, E., \& Padilla, R. (1995). Social integration and academic performance among minority university students. Journal of College Student Development, 36(6), 542-552.

32 Moller-Wong, C. \& Eide, A. (1997). An engineering student retention study. Journal of Engineering Education, $86(1), 7-15$.

33 National Academies, (2010) Rising Above the Gathering Storm, Revisited: Rapidly Approaching Category 5, National Academies of Sciences, National Academy of Engineering, and Institute of Medicine of the National Academies, National Academies Press. http://www.aps.org/policy/reports/upload/ragsrevisited.PDF

${ }^{34}$ National Action Council on Minorities in Engineering, Inc. (NACME). (2008). Confronting the 'New' American Dilemma, Underrepresented Minorities in Engineering: A Data-Based Look at Diversity, National Action Council for Minorities in Engineering, Inc. (NACME), Commission on Professionals in Science and Technology (CPST). Retrieved September 15, 2012. http://www.nacme.org/user/docs/NACME\%2008\%20ResearchReport.pdf

35 National Action Council on Minorities in Engineering, Inc. (NACME). (2012). American Indians in Engineering, NACME Research \& Policy, 2(2), July 2012.

36 National Science Board (NSB). 2010. Science and Engineering Indicators 2010. Arlington, VA: National Science Foundation (NSB 10-01).

${ }^{37}$ National Science Foundation (NSF). (2011). Division of Science Resources Statistics. (2011). Women, Minorities, and Persons with Disabilities in Science and Engineering: 2011, Special Report NSF 11-309. Arlington, VA. Available at http://www.nsf.gov/statistics/wmpd/

${ }^{38}$ Nicholls, G., Wolfe, H., Besterfield-Sacre, M. \& Shuman, L. (2010). Predicting STEM degree outcomes based on eighth grade data and standard test scores. Journal of Engineering Education, 99(3), 209-223.

39 Nord, C., Roey, S., Perkins, R., Lyons, M., Lemanski, N., Brown, J., and Schuknecht, J. (2011). The Nation's Report Card: America's High School Graduates (NCES 2011-462). U.S. Department of Education, National Center for Education Statistics. Washington, DC: U.S. Government Printing Office.

40 Padilla, R., Trevino, J., Gonzalez, K., \& Trevino, J. (1997). Developing local models of minority student success in college. Journal of College Student Development, 38(2), 125-135.

41 Pavel, D. M., Skinner, R. R., Farris, E., Cahalan, M., Tippeconnic, J., \& Stein, W. (1998). American Indians and Alaska Natives in postsecondary education. U.S. Department of Education, National Center for Education Statistics. Washington D.C.: U.S. Government Printing Office.

42 Tinto, V. (1993). Leaving college: Rethinking the causes and cures of student attrition (2nd ed.). Chicago: The University of Chicago Press.

43 Tinto, V. (2000). Linking learning and leaving: Exploring the role of the college classroom in student departure. In J. Braxton (Ed.), Rethinking the student departure puzzle: New theory and research on college student retention (pp. 81-94). Nashville, TN: Vanderbilt University Press.

${ }^{44}$ Usher, E. L., \& Pajares, F. (2009). Sources of self-efficacy in mathematics: A validation study. Contemporary Educational Psychology, 34(1), 89-101. 
45 Zhao, C., \& Kuh, G. D. (2004). Adding value: Learning communities and student engagement. Research in Higher Education, 45(2), 115-138.

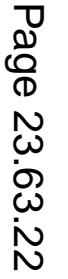

